\title{
STRICT LIABILITY: A SOLUTION TO HOLD PEATLAND DESTROYERS ACCOUNTABLE
}

\author{
${ }^{1}$ Bayu Novendra, ${ }^{2}$ Kania Jennifer Wiryadi \\ ${ }^{1}$ Faculty of Law, Universitas Indonesia, Depok, Indonesia \\ ${ }^{2}$ Faculty of Law, Universitas Indonesia, Depok, Indonesia \\ 1 bayunovendra5@gmail.com ${ }^{2}$ kaniawiryadi@gmail.com
}

\begin{abstract}
In 2019, burned forests and peatlands reached 328 thousand hectares. The World Bank estimates that total loss from this event reached 5.2 billion USD. At least, until September 2019, there were 900,000 residents who experienced respiratory health problems and hundreds of schools in Indonesia, Malaysia and Singapore had to stop teaching and learning activities due to the haze. One of the factors that 'fertilizes' problems for destruction of forests and peatlands that continue to grow is difficulty to account the perpetrator. This paper will attempt to answer and solve these problems with the concept of strict liability. This research will answer two problems, what is strict liability and how the concept of strict liability can solve the issues for peatland law enforcement? And how the peatland regulation that has been implemented and the application of strict liability as a repressive rule? Strict liability concept means that the defendant will still be responsible even though his activities were lawful and carried out carefully. Furthermore, strict liability is an accountability that not only eliminates elements of subjective error, but also objectively. The government has pursued a moratorium policy. Starting from Presidential Instruction (Inpres) No. 10 year 2011 and extended by Inpres No. 6 year 2013 also Inpres No. 8 year 2015. However, this policy is considered unsatisfactory because there are still forestry and plantation permits issued by the government and massive forest and land burning. Therefore, there needs a solution from a repressive approach to provide a deterrent effect on forest fire perpetrators. Strict liability has been proven to be implemented in peat cases based on Indonesian court decisions.
\end{abstract}

Keywords: Forest Fire, Law Enforcement, Moratorium, Peatland, Strict Liability

DOI: $10.33541 /$ sp.v21i3.2265

Sociae Polites : Majalah IImiah Sosial Politik

Faculty of Social and Political Science, Universitas Kristen Indonesia

ISSN 1410-3745 print/ ISSN 2620-4975 online

Volume 21, Number 2 (Youth Peatland Conference)

Pages 147-158 


\section{Introduction}

The constitution guarantees the accommodation of a good and health environment for growth and development. This provision is guaranteed in Article 28H paragraph (1) of the 1945 Constitution of the Republic of Indonesia which reads, "Every person has the right to live in physical and mental well-being, to have a place to live, and to have a good and healthy living environment and the right to obtain health services" The right to live and have a good and healthy living environment can be juxtaposed with Article 25 of the Universal Declaration of Human Rights (UDHR) which regulates the right to an adequate standard of living for the health and well-being of both himself and his family. In addition, Article 12 paragraph (1) of the International Covenant on Economic, Social and Cultural Rights provides that States Parties recognize the right of everyone to enjoy the highest standard of physical and mental health. This means that the necessities of life, including life support for Indonesian citizens, must be fulfilled (Faiz 2015, 711).

However, in practice, the trend of pollution and environmental damage tends to increase, especially on peat soils. This is because peat has a unique character, which is that it can store embers to a certain depth in the form of wood scraps in the presence of oxygen in the pore space of the peat. (BRG Indonesia 2020). In 2019 there were 329,722 hectares of forest and burned land in Indonesia (BPS 2019, 288). This figure is almost twice the total area of forest and land burned in the previous two years (BPS 2019, 288). During the last ten years, the largest area of forest and land fires occurred in 2015 with a total area of 2,611,411.44 hectares (BPS 2019, 288). The forest and land fires that occurred in 2015 were man-made with more than 100,000 fires being burned to prepare agricultural land. (Global Fire Data 2020). Based on World Bank calculations, the losses for the country due to the fires in 2015 were estimated at IDR221 trillion (World Bank 2016).

To deal with forest and land fires, the government has made preventive measures, namely the moratorium. The moratorium itself is a legal policy to postpone obligations for a specified time limit (Dictionary). Mortarium policy has existed since the era of President Susilo Bambang Yudhoyono's administration starting from Presidential Instruction No. 10/2011, was extended by Presidential Instruction No. 6/2013, then Jokowi continued the moratorium with Presidential Instruction No. 8/2015. However, during the period the moratorium did not appear to be effective. First, government still granted forestry and plantation permits through the revision of the moratorium area and the release of forest areas (Mongabay 2017). Second, there is still massive forest and land burning in the opening of oil palm plantations (Mongabay 2017). Reflecting on the moratorium policy, it seems that repressive law enforcement is not effective enough, so the author offers a solution, namely the concept of strict liability as a solution with a concept of repressive law enforcement.

Based on the background explanation above, the author will review from the side of legal enforcement effectiveness with the formulation of the question, what is strict liability and how the concept of strict liability can solve the issues for peatland law enforcement? And how the peatland regulation that has been implemented and the application of strict liability as a repressive rule? 


\section{Literature Review}

There are several reasons why it is important to carry out civil accountability in order to enforce environmental laws. First, to provide an opportunity for victims to compensate those who caused the losses. In short, civil suit/liability will provide a legal basis which obliges polluters, in the sense of those who caused pollution or loss, to pay compensation to victims (Wibisana 2017, 2). Second, lawsuit/accountability can provide an opportunity for victims to request a court decision in the form of a court order. In literature, a court order decision like this is referred to as a mandatory injunction, namely a court order requiring the defendant to rectify the damage that has occurred.

Third, van Dam stated that civil accountability can also have a function as recognition and satisfaction. In this case, civil liability serves to show legal recognition that someone is guilty or responsible for a loss (Dam 2006, 302-303). Fourth, civil liability can also function as a punishment for an injurious act. This is especially true if the detrimental act was committed on purpose. The purpose of this punishment can be seen from the punitive damages (Dam 2006, 303).

There are at least two theories or models used in the context of civil liability, namely unlawful acts (perbuatan melawan hukum) or strict liability. Judging from its nature, basically court decisions can be divided into declarative decisions, consitutive decisions, and condemnatory decisions. (Hukumonline 2020) Declaratoir or declarative decisions (declatoir vonnis) are statements of judges that are contained in the decisions they render. The statement is an explanation or determination of a right or title or status and the statement is included in the injunction or dictum of the decision. A constitutief verdict is a decision that ensures a legal condition, either negating a legal condition or creating a new legal condition. Meanwhile, the condemnation verdict is a verdict which contains punishing one of the parties in a case. A condemnatory decision is an inseparable part of a declarative or constitutive rule (Harahap 2016, 877). The type of decision that is more often related to criminal liability in the context of environmental law is the condemnatoir decision. In this case, the court decided to sentence the defendant to pay compensation and/or to commit or stop certain acts (Wibisana 2017,8). This is in line with van Dam's view that civil liability can only be effective if the law provides remedies, either in the form of damages, or in the form of injunction in the form of a court order to commit or stop certain acts (Dam 2006, 302-303). In the context of damages, it is known in various literatures that there are several types of compensation. The compensation includes nominal compensation, compensation for punishment, actual compensation, and mixed compensation (Nugroho 2012, 568).

Meanwhile, in relation to injuction, the Black's Law Dictionary defines this term as an order from a court to a certain party (usually the defendant) to take certain actions or to prevent or stop certain actions from being carried out. More clearly, the term "Injunction" refers to a court order to order or prevent an action from being carried out (Garner, 855). Thus, basically, injuction is a court order, which instructs someone to do something, or prohibits someone from doing something. In another sense, injuction is also a writ that orders to do or not do something, including an order issued by a court of equity (Garner, 855) 


\section{Research Methods}

The research method used in this paper is normative juridical legal research, or often referred to as dogmatic legal research or theoretical legal research. This normative legal research provides written emphasis on research on library law materials. In analyzing legal materials, this study uses descriptive qualitative analysis, which describes existing data or cases descriptively to draw conclusions from the data. Drawing conclusions using the deductive method, namely by drawing conclusions from general questions to reach specific conclusions. The legal materials used consist of primary and secondary legal materials. Primary legal materials are binding legal materials such as basic norms or rules, while secondary legal materials are legal materials that provide an explanation of primary legal materials.

\section{Results and Discussions}

a. Concept of Strict Liability to Solve the Issues for Peatland Law Enforcement The principle of Strict Liability is one of the ideas conveyed in Law Number 32 of 2009 concerning Protection and Management of the Environment, Article 88, namely: "Every person whose actions, business and/or activities use B3, produce and/or manage B3 waste, and/or those that pose a serious threat to the environment are absolutely responsible for the losses incurred without the need to prove the element of fault". In the elucidation of Article 88 it is explained that what is meant by absolute responsibility is "the element of fault does not need to be proven by the plaintiff as the basis for paying compensation". In the view of the law, the needlessness for prove fault is a special rule (lex specialis) from an act of breaking the law.

Strict liability is a form of civil liability that differs from Tort liability. Even if the actions are legal and carefully carried out, the defendant would still be held liable under strict liability. Furthermore, strict liability is a type of accountability that excludes not only subjective but also factual elements of fault. Strict liability is a model of civil liability for losses arising from activities that pose a serious threat to the environment or abnormal dangerous activities. Kolosa and Mayer shared a similar opinion regarding the requirements or not the strict liability teachings can be applied, namely: "Extra-hazardous activities and dangerous animals can be the occasion for determining strict liability. The activities must be such that they are not in common usage in the community and involve risk of serious harm to persons or property that cannot be eliminated by the use of due care". (Imamulhadi 2013, 417-432)

Whereas a serious threat is the occurrence of environmental pollution and/or damage, the impact of which has the potential to be irreversible and/or environmental components that are very widely affected, such as human health, surface water, ground water, soil, air, plants and animals (Chief Justice Decree No. 036/KMA/SK/II/2013). The conclusions can be drawn in the form of two elements of serious threats which are a requirement for an activity to be called an abnormal dangerous activity. The potential for permanent losses is the first serious thread. Second, the existence of a multidimensional potential impact will indicate a serious thread too. Based on that basis, activities related to peat and forest fires can be classified as activities that pose a serious threat so that they are subject to strict liability (Wibisana 2017).

In the case of Minister of Environment v. PT Kalista Alam, the plaintiff (Government) often argues that forest or peatland fires have the potential to cause 
irreversible losses. In addition, forest or peatland fires can cause disruption to the lives of many people, for example in the form of disruption of flights, which can also cause multidimensional impacts. It becomes clear that the problem of peat destruction can be subject to strict liability. In recent years, strict liability has begun to be widely used in Indonesian courts. Furthermore, some judges' decisions have even used strict liability as a judgement without being juxtaposed with tort, such as the judgement of Bale Bandung District Court No. 735/ PDT.G-LH/2018/ PN.Jkt.Utr and the judgement of Jakarta Utara District Court No. 178/Pdt.G / LH / 2019 / PN Blb. The judges in both cases stated in their judgement that the defendant was absolutely responsible for polluting the environment.

James Krier stated that the doctrine of strict liability for abnormally dangerous activities can be of assistance in many cases of environmental damage, strict liability is, of course, more than a burden-shifting doctrine, since it not only relieves the plaintiff of the obligation to prove fault but forecloses the defendant proving the absence of fault. (Imamulhadi 2013, 417-432) Krier's opinion is crucial in order to avoid misunderstandings and mistakes in its use in court. It is important to note that strict liability is not the same as res ipsa loquituror or reverse proof of the element of fault or what Krier calls as burden-shifting doctrine.

Goldberg and Zipursky concluded that the enforcement of res ipsa loquitur must meet the following requirements. First, that an event that was detrimental to the plaintiff could only have occurred because of someone's carelessness. Second, that the instrument of injury is completely under the control of the defendant. Third, the loss occurred without the active participation of the plaintiff himself, so it can be said that the plaintiff in the res ipsa loquitur is a passive plaintiff. (Goldberg and Zipursky 2010, 153-154)

Meanwhile Harpwood expressed a slightly different opinion. Harpwood stated that the requirements to apply the res ipsa loquitur doctrine are: a) the loss is a loss that is difficult to prove the cause. In this case, the "unknown cause" element must be met; b). losses are deemed to only occur due to lack of prudence, or because of negligence; and c) the defendant must have complete control over the situation. This last element is an explanation as to why the defendant is assumed to have been proven to have committed negligence. (Vivienne Harpwood 2000, 153-154). Meanwhile, Judge Phillips asserted in John B. Wells v. Norfolk Southern Railway Company, et al (2005) stated that the res ipsa loquitur is not a rule about accountability, but about proof.

The scholars' views on res ipsa loquitur or the reverse proof of the element of fault indicates that res ipsa loquitur is not entirely a strict liability since it is still also an accountability based on mistakes (Tort liability). This conclusion is based on two reasons. First, strict liability does not embrace to reverse burden of proof. In the strict liability, the plaintiff still has to prove the existence of a loss and a clausal relationship between the loss and the defendant's activities. Second, in strict liability, the defendant still has to be responsible even though he is able to prove that his activity/act was not an act against the law, whereas in reverse burden of proof (especially in the case of a legal claim), the defendant will be free from responsibility if he is able to prove that his actions were not against the law.

So, in strict liability, there only a necessity to prove loss and causality without the need to prove fault at all. What is meant by causality is whether there is a relationship between the potential perpetrator and the losses incurred, while what is meant by fault is: (Rosa Agustina 2003, 36-37) 
a. Infringing on other people's subjective rights. This subjective right is defined as both individual rights and as the right to property;

b. In violation of the perpetrator's legal obligations, whether such obligations be written in written law or those formulated in unwritten law;

c. In violation of the norms of decency, namely contrary to the norms recognized as legal norms.

This is emphasized in the basic concept of strict liability. The strict liability concept does not care that an entrepreneur has carried out his business prudently or has taken preventive measures in such a way and is in accordance with the law, if there is a loss and the causality, the business actor can be held accountable.

The principles of European civil liability (Principles of European Tort Law) include the application of strict liability into the principles. In these principles, strict liability is formulated in Article 5: 101 paragraph (1) which states that "[a] person who carries on abnormally dangerous activity is strictly liable for damage characteristic to the risk presented by the activity and the results from it". In fact, especially with regard to environmental issues, strict liability has also been adopted in the Environmental Liability Directive (ELD), Directive 2004/35/ CE. According to this Directive, those who carry out certain activities are responsible for bearing the costs of preventing and restoring environmental losses that occur from these activities. A person will be free from responsibility if losses are caused by act of armed conflict, hostilities, civil war, insurrection, and exceptional natural disasters, are inevitable, and cannot be inhibited (irresistible).

Besides that, US has been practicing strict liability for a long time in its legal practice. One of the forerunners the uses of strict liability in the US can be considered in the court of Appeals of New York judgment in Hay v. Cohoes Co. (1849). In this case the court stated that even though the defendant legally owned his property, and even though the defendant's activities were not illegal, the defendant was still responsible for the losses suffered by the plaintiff. As the reason for this decision, Judge Gardiner argues that property rights are not absolute rights, because the use of these rights is limited by the rights of others. This decision is considered as the initial application of strict liability because the defendant is considered responsible for the losses suffered by the plaintiff, even though the defendant's activities are not illegal. In addition to explosives, judges also apply strict liability for losses arising from mining, in this case oil drilling.

Strict liability increasingly being applied in the US to harm arising from dangerous activities (abnormal dangerous or ultras-hazardous activities) after the American Law Institutes published this liability rule in Restatements of Torts. According to Restatement (second) of Torts 519 (1977) subsection (1), everyone who engages in dangerous activities is responsible for the losses incurred, even though that person has taken very careful measures to prevent losses. Whether or not it is intentional or negligent is not the basis for strict liability. Accountability in this case arises because of the danger from an activity, and not from the way the activity is carried out. Thus, the condition for this accountability is the existence of dangerous activities with losses incurred.

Restatement (second) of torts expressly states that liability based on strict liability is limited to activities that are extremely dangerous (abnormally dangerous). To provide guidance to the court in determining what activities are subject to strict liability, the Restatement (second) of torts provides a testing tool to determine whether an activity is considered a very dangerous activity or not, here are these factors, (Restatement of Torts 520) 
"In determining whether an activity is abnormally dangerous, the following factors are to be considered: (a) existence of a high degree of risk of some harm to the person, land, or chattels of others; (b) likelihood that the harm that results from it will be great; (c) inability to eliminate the risk by the exercise of reasonable care; (d) extent to which the activity is not a matter of common usage; (e) inappropriateness of the activity to the place where it is carried on; and (f) extent to which its value to the community is outweighed by its dangerous attributes."

From these factors, the American Law Institute basically considers that the six factors/criteria are equally important and should be considered. However, the American Law Institute opens up the possibility for judges to emphasize certain factors, particularly those related to the large degree of danger from the activity, as well as the mismatch between the activity and the place where the activity is carried out. For this reason, the locality factor is the most determining factor in assessing whether an activity is a dangerous activity or not (Mabane 1979, 79).

The formulation of civil liability for highly hazardous activities can be found not only in the Restatement (Second) of Torts, but also in several legislative products in the US, for example the Clean Water Act (CWA), Oil Pullution Act (OPA), Comprehensive Environmental Response, Compensation, and Liability Act (CERCLA). This shows that the development of strict liability in the US occurs in two ways. First, the adoption of strict liability in Restatement (Second) of Torts 1977. The enforceability of this strict liability model really depends on whether the defendant's activities fall into the category of abnormally dangerous activities or not. In this case, the judge will determine whether an activity is subject to strict liability or not (Wibisana 2017, 87).

Second, is the adoption through statutory regulations as previously mentioned. Related to the second model, there are several characteristics of the use of strict liability in the second model. First, strict liability in this model is regulated more firmly, but on the one hand it is limited in scope by this law (Wibisana 2017, 87). Then, there is channeling of responsibility (channeling liability). The canalization of liability occurs when the law identifies a particular party, and then determines that that party will be exclusively responsible for the losses incurred (Liu Jing 2013, 65). Third, there is a limitation on the amount of accountability (financial caps), which Faure has criticized because it is considered a serious interference to the rights of victims (Faure 1996, 94). Fourth, there is mandatory financial responsibility.

To link it back activities related to peat and forest fires can be classified as activities that pose a serious threat so that they are subject to strict liability. Forest or peatland fires can cause disruption to the lives of many people, for example in the form of disruption of flights, which can also cause multidimensional impacts. It becomes clear that the problem of peat destruction can be subject to strict liability.

\section{b. Overview of Peatland Regulation and the Application of Strict Liability as a Repressive Rule}

The danger of activities on peat is evident from the number of cases of forest fires that has led to a peat moratorium policy. Moratorium itself means a suspension or postponement (penangguhan or penundaan) (KBBI 2021). Meanwhile, in the financial sector, moratorium is a deferment of payments based on law in order to prevent an increasingly severe financial crisis (KBBI 2021). In the case of peat and forestry, the 
definition of a moratorium proposed by non-governmental organizations in the environmental sector is a period of stopping logging and forest conversion activities in order to distance themselves from the problem for a long-term and permanent solution (WALHI). With the aim of finding the best way to get out of the various negative impacts of the forestry industry sector, the first step is to restore forest and peat swamp ecosystems, improve governance performance, law enforcement and certainty, and deforestation management (WALHI).

The moratorium began in the era of President Susilo Bambang Yudhoyono's administration with Presidential Instruction Number 10 of 2011 dated May 20, 2011 concerning the Postponement of Granting New Permits and Improving Management of Primary Natural Forests and Peatlands and was extended by Presidential Instruction Number 6 of 2013. This moratorium Presidential Instruction was influenced by the signing of Letter of Intent on REDD +.

In terms of statutory regulations (peraturan perundang-undangan), the legal product of the moratorium policy is a Presidential Instruction. Presidential Instruction according to Jimly Asshiddiqie is a policy rule or beleidsregels, namely a form of policy regulation that cannot be categorized as ordinary statutory regulations (peraturan perundang-undangan) (Asshidiqqie 2004, 20) or not in the form of official regulations (Asshidiqqie 2004, 391). For example, a letter from the Minister which is addressed to all civilian apparatus of the state who are within the scope of their responsibility, can be stated in an ordinary letter, not an official regulation. However, its content is regeling and provides guidance (Tobing, 2012). This letter is commonly called beleidsregel.

In this Presidential Instruction Number 10 Year 2011, there is a postponement of the issuance of new licenses for primary natural forest (hutan alam primer) and peat land located in conservation forest (hutan konservasi), protected forest (hutan lindung), production forest (hutan produksi (limited,regular/permanent, which can be converted). This Presidential Instruction is addressed to three ministers (Forestry, Home Affairs and the Environment) and the heads of five institutions (the Presidential Work Unit for Development Supervision and Control, the National Land Agency, the National Spatial Planning Coordinating Board, the National Survey and Mapping Coordinating Agency and other established institutions. to manage REDD+) as well as governors and district heads. As a non-legislative document, the Presidential Instruction has no legal consequences if it is not implemented by the party receiving the instructions especially for the regional apparatus because the governor and regent as regional heads are directly elected by the community (Mongabay). After the Joko Widodo's administration era, the Moratorium was continued with Presidential Instruction Number 8 of 2015.

This Presidential Instruction uses the terms primary natural forest (hutan alam primer) and peat land. The term primary natural forest is the FAO (Food and Argiculture Organization) definition and thus makes reporting easier. According to FAO, primary forest is forest consisting of native types of trees that grow naturally, have no clear signs of human activity and ecological processes, and are not significantly disturbed (FAO 2010). According to the Ministry of Forestry, for practical reasons, 'primary natural forest' was intended to imply that the area had never been issued a permit (Mongabay). Some of the problems in using the term primary natural forest are (Mongabay, 5):

a. The term primary natural forest has never been used in forestry policies in Indonesia. In law only the terms and definitions of forests and forest areas are known based on ecological functions and based on their administrative 
functions or status. If the term of primary natural forest is legally unknown, there is a concern that law enforcement will confusing;

b. The use of the term primary natural forest affects the scope for suspension of licensing because it does not include secondary natural forest or loggedover forest, which may be partly better managed as forest than if it is converted or for other uses. Whereas secondary forest covers more than the forest area in Indonesia.

During the two government regimes, the moratorium policy proved ineffective. First, there is still the issuance of forestry and plantation permits by the government through revisions to the moratorium area and the release of forest areas. The revision of the moratorium area from 2011 to 2013, reduced 5,055,089 hectares (Aji 2019, 189). In 2015 , moratorium area was added to $2,353,151$ hectares. The inconsistency in the application of the moratorium area opens opportunities for the issuance of new permits, both forestry and plantation business permits through the release of forest areas (Aji 2019, 189). Second, there is still massive forest and land burning in the opening of oil palm plantations, especially in the three main islands of Indonesia, Sumatra, Kalimantan and Papua. The World Bank noted, in 2015 alone there was an area of 2.6 hectares of burned land in oil palm plantations causing losses of up to 221 trillion rupiah (Firmansyah, 2017).

Through Presidential Instruction Number 8 of 2018 concerning Suspension and Evaluation of Oil Palm Plantation Licenses and Increasing Productivity of Oil Palm Plantations, the focus of the moratorium is no longer on forests and peat but on oil palm. This focus is influenced by non-governmental organizations due to several things, namely (Saturi in Aji 2019, 189): low productivity of oil palm plantations, potential for perpetuating forest and land power, escalation of agrarian conflicts along with plantation expansion, the realization of inappropriate oil palm plantation development. from planning, plantations without permits, modern slavery practices in oil palm plantations, and inconsistencies in the peat ecosystem policies.

Law enforcement consists of preventive and repressive strategies (Hamzah 2004, 54). Based on the previous explanation, it is known that the fire prevention strategy in peatlands by suspending permits on peat soils is not very effective. Therefore, the use of strict liability as civil law enforcement can be applied to reduce disasters caused by peatland fires by irresponsible actors.

In first explanation, it can be concluded that activities related to peat and forest fires can be classified as activities that pose a serious threat so that they are subject to strict liability. Forest or peatland fires can cause disruption to the lives of many people, for example in the form of disruption of flights, which can also cause multidimensional impacts. It becomes clear that the problem of peat destruction can be subject to strict liability.

Several decisions that have implemented strict liability in the case of peat fires can be seen in the Palembang Court Decision Number 234/Pdt.G/LH/2016/PN Plg between the Ministry of Forestry and the Environment as the Plaintiff and PT Waimusi Agroindah as the Defendant. This case is peatlands or wetlands damaged case due to ignoring fires on an area of 580 hectares. In their consideration, the judge took the expert opinion of Basuki Wasis, Asmadi, and Basuki Sumawinata that peat has a serious nature impact, namely,

a. Basuki Wasis (Supreme Court 2016, 116) stated that peat soil is formed from the accumulation of leaves and branches of fallen trees 4,000 to 6,000 years ago, decomposition or rotting. The peat growth rate per year is only 0 
to 0.5 millimeters, so that if it burns just 20 to $30 \mathrm{~cm}$, it will take more than 1,000 (one thousand) years to recover;

b. Asmadi (Supreme Court 2016, 116) stated that peat cannot be formed or made, peat is formed by itself, the accumulation of fallen leaves, branches of trees or plants for thousands of years [can be around 5,000 (five thousand) to 6,000 (six thousand)] years. If the peat burns only $30 \mathrm{~cm}$, it means that the peat cannot be recovered or replaced suddenly, but it must wait for 1,000 (one thousand years).

c. Basuki Sumawinata (Supreme Court 2016, 116) stated that even only $30 \mathrm{~cm}$ of peatland is burned, it is certain that the peat is damaged.

Based on the expert's opinion, burnt peat or peatland is destroyed and cannot be recovered (irreversible) in the near future, this is a serious threat category (vide Decree of the Chief Justice of the Supreme Court of the Republic of Indonesia number 36/KMA/SK/II/2013). The judge also partially granted the plaintiff's claim and stated that the Defendant was strictly responsible (strict liability) for compensation for restoration due to environmental damage caused by fire. The Defendant was decided to compensate for a loss of $\mathrm{Rp}$. $29,658,700,000.00$ by the judge.

\section{Conclusions and Recommendations}

Based on the article above, it can be concluded that strict liability can be effective as a form of civil liability for peat. Strict liability is one of the bases of civil liability which is different from Unlawful Acts. In the strict liability, the defendant will still be responsible even though the activities are lawful and carried out carefully. The application of strict liability in the case of peat can be seen in the case of the Minister of Environment v. PT Kalista Alam. One thing that is important to understand is that strict liability is not the same as resistance claim or inverse proof of the element of error.

The government has pursued a moratorium policy as an effort to resolve problems in peatlands. Starting from Presidential Instruction No. 10 of 2011 was extended by Presidential Instruction No. 6 of 2013 and Presidential Instruction No. 8 of 2015. However, this policy is not satisfactory because the government still issued forestry and plantation permits and there are still massive forest and land fires. Therefore, there needs to be a solution from a repressive approach to provide a deterrent effect on the perpetrators of forest fires. Strict liability has also been shown to be applicable in peat cases based on court decisions in Indonesia. 


\section{BIBLIOGRAPHY}

\section{Book}

Agustina, Rosa. 2003. Perbuatan Melawan Hukum. Jakarta: Pascasarjana FHUI.

Andri G. Wibisana. 2017. Penegakan Hukum Lingkungan Melalui Pertanggungjawaban Perdata,Cet. 1. Depok: Badan Penerbit FH UI.

Asshidiqqie, Jimly. 2010. Perihal Undang-Undang. Jakarta: Konstitusi Press.

Badan Pusat Statistik. 2019. Statistik Lingkungan Hidup Indonesia 2019. Jakarta: Badan Pusat Statistik.

Coleman, Jules. 1992. Risks and Wrongs. London: Cambridge University Press.

Dam, Cees van. 2006. European Tort Law. Oxford: Oxford University Press.

Food and Agriculture Organization. 2010. Global Forest Resources Assessment. Roma.

Garner, Bryan A. 2009. Black's Law dictionary. St. Paul, MN: West Publishing Co.

Goldberg, John C.P. and Benjamin C. Zipursky. 2010. The Oxford Introductions to U.S Law: Torts. Oxford: Oxford University Press.

Harahap, Yahya. 2016. Hukum Acara Perdata Tentang Gugatan, Persidangan, Penyitaan, Pembuktian, dan Putusan Pengadilan. Jakarta: Sinar Grafika.

Harpwood, Vivienne. 2000. Principles of Tort Law, $4^{\text {th }}$ ed. London: Cavendish Publishing Limited.

Lotulung, Paulus Effendie. 1993. Penegakan Hukum Lingkungan oleh Hakim Perdata. Bandung: Citra Aditya Bakti.

Nugroho, Susanti Adi. Hukum Persaingan Usaha di Indonesia dalam teori dan Praktik serta Penerapan Hukumnya. Jakarta: Kencana Prenada Media Group.

Wibisana, Andri Gunawan. 2017. Penegakan Hukum Lingkungan Melalui Pertanggungjawaban Perdata. Depok: BP-FHUI.

\section{Journal}

Aji, Sekar Banjaran. "Moratorium Sawit Jokowi dalam Perspektif Kebijakan Pembangunan Berkelanjutan ala Politik Hijau." Jurnal Hukum Lingkungan Indonesia Vol 5 No 2 (2019).

Faiz, Pan Mohammad. 2016. "Perlindungan terhadap Lingkungan dalam Perspektif Konstitusi," Jurnal Konstitusi Vol 13 No 4.

Faure, Michael. 1996. "Economic Aspects of Environmental Liability: An Introduction," European Review of Private Law, Vol. 4.

Imamulhadi. 2013. "Perkembangan Prinsip Strict Liability dan Preacautionary Dalam Penyelesaian Sengketa Lingkungan Hidup Di Pengadilan," Mimbar Hukum Volume 25, Nomor 3.

Liu Jing. 2013. "Compensating Ecological Damage Comparative and Economic Observations," disertasi, Maastrict University (2013).

\section{Websites}

Badan Restorasi Gambut. 2020. "Karakteristik Gambut dan Pencegahan Kebakaran." Accessed on 20 October 2020. https://brg.go.id/karakteristik-gambut-danpencegahan-kebakaran/ 
Global Fire Data. 2020. "Global Fire Emissions Database." http://www.globalfiredata.org/index.html. Accessed on 20 October 2020.

Hukumonline. 2020. "Arti Putusan Deklarator, Putusan Constitutief dan Putusan Condemnatoir." Accessed on 20 October 2020. https://www.hukumonline.com/klinik/detail/ulasan/lt58ed9048160ee/arti-putusandeklarator--putusan-constitutief-dan-putusan-condemnatoir/\#_ftn5.

Mongabay. 2017. "Moratorium Izin Hutan dan Gambut, Berjilid-jilid (Tanpa) Ada Perbaikan?," Accessed on $20 \quad$ October 2020. https://www.mongabay.co.id/2017/05/28/opini-moratorium-izin-hutan-dangambut-berjilid-jilid- tanpa-ada-perbaikan/.

Tobing, Letezia. 2012. "Perbedaan Keputusan Presiden dengan Instruksi Presiden." $\begin{array}{llll}\text { Accessed } & \text { on } & \text { March } & \end{array}$ https://www.hukumonline.com/klinik/detail/ulasan/lt50cf39774d2ec/peraturanpresiden/

WALHI. "Moratorium 25 Tahun Menghentikan Deforestasi dan Menyelesaikan Konflik." Accessed on 1021. https://www.walhi.or.id/index.php/moratorium-25-tahun-menghentikandeforestasi-dan-menyelesaikan-konflik

World Bank. 2018. "Kerugian dari Kebakaran Hutan Analisa Dampak Ekonomi dari Krisis Kebakaran tahun 2015." Accessed on 25 October 2020. https://openknowledge.worldbank.org/bitstream/handle/10986/23840/Forest\%20F ire\%20Notes $\% 20$ -

\%20Bahasa\%20final $\% 20$ april $\% 2018$.pdf? sequence $=6 \&$ isAllowed $=\mathrm{y}$. 